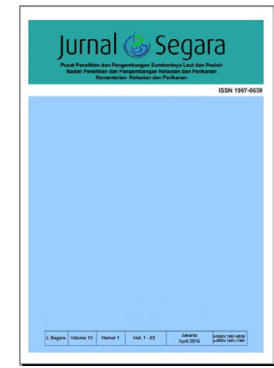

JURNAL SEGARA

http://ejournal-balitbang.kkp.go.id/index.php/segara

ISSN : 1907-0659

e-ISSN : 2461-1166

Nomor Akreditasi: 766/AU3/P2MI-LIPI/10/2016

\title{
PENGARUH PENAMBANGAN PASIR LAUT TERHADAP KEKERUHAN PERAIRAN TELUK BANTEN SERANG
}

\section{MARINE SAND MINING IMPACT ON WATER TURBIDITY IN BANTEN COASTAL BAY OF SERANG}

\author{
Zuleha Ernas ${ }^{1,2)}$, M. Hasroel Thayib ${ }^{1)}$ \& Widodo S. Pranowo ${ }^{3,4)}$ \\ 1) Pascasarjana IImu Lingkungan, Universitas Indonesia \\ 2)Direktorat Jenderal Pengawasan Sumber Daya Kelautan dan Perikanan, KKP \\ 3)Laboratorium Data Laut \& Pesisir, Pusat Riset Kelautan, KKP \\ ${ }^{4)}$ Prodi Teknik Hidrografi, Sekolah Tinggi Teknologi Angkatan Laut, TNI-AL
}

Diterima : 3 Januari 2016 ; Selesai Perbaikan : 26 Maret 2018 ; Disetujui Setelah Perbaikan: 9 April 2018

\begin{abstract}
ABSTRAK
Pesatnya pertumbuhan ekonomi dan penduduk di daerah pesisir menjadikan kebutuhan akan ruang yang lebih luas sehingga reklamasi kawasan pesisir menjadi pilihan utama yang banyak ditempuh. Pemanfaatan pasir laut yang berlebihan dan tidak terkendali dapat merusak daya dukungnya. Penelitian ini bertujuan untuk mengkaji gangguan pada kekeruhan perairan Teluk Banten Kabupaten Serang yang disebabkan kegiatan penambangan pasir laut pada periode 2004-2015. Penelitian ini menggunakan metode analisis korelasi dan regresi polinomial orde 2. Penambangan pasir laut oleh sebuah perusahan swasta dilakukan di Teluk Banten pada perairan Desa Lontar Kecamatan Tirtayasa Kabupaten Serang dan Desa Pulo Panjang Kecamatan Pulo Ampel Kabupaten Serang. Penambangan dilakukan mulai tahun 2004 hingga 2015, dengan total produksi hingga Januari 2015 adalah $11.513 .972 \mathrm{~m}^{3}$. Hasil penelitian menunjukkan hubungan yang kuat $(r=0,9835)$ antara penambangan pasir laut dengan peningkatan kekeruhan perairan Teluk Banten dengan persamaan regresi, $y(x)=$ $90,8494+9,2392.10^{-3} x-1,3059 \cdot 10^{-7} x^{2}$. Disarankan aktivitas penambangan pasir laut dapat dipertimbangkan untuk dihentikan sementara karena telah meningkatkan TSS perairan Teluk Banten hingga melampaui ambang batas baku mutu lingkungan.
\end{abstract}

Kata kunci: Penambangan pasir laut, kekeruhan perairan, Teluk Banten.

\section{ABSTRACT}

A rapid economic and population growths in urban coastal areas maybe followed by an expansion of space. Mostly, the expansion is by applying a coastal reclamation. An uncontrollable and overexploitation of marine sand for coastal reclamation may cause damage to its carrying capacity. This research is aimed to find out the disturbance of marine turbidity in Banten Coastal Bay Serang District caused by marine sand mining activity in 2004-2015. The research used a statistically correlation and 2 nd order of polynomial regression method. Marine sand mining was carried out by a private company located in Banten Coastal Bay on Lontar Village, Tirtayasa Sub-district and Pulo Panjang Village, Pulo Ampel Sub-district Serang District. The mining has been conducted from 2004 to 2015, with total production up to January 2015 reached $11.513 .972 \mathrm{~m}^{3}$. The results showed the strong correlation ( $r=0.9835)$ between marine sand mining production and the increasing of water turbidity in Banten Coastal Bay which represent by a regression equation $y(x)=90.8494+9.2392 .10^{-3} x-1.3059 .10^{-7} x^{2}$. It is temporarily considered to postpone the marine sand mining activities as it has increased the water turbidity of Banten Bay above the standardized environmental quality threshold.

Keywords: Marine sand mining, marine turbidity, Banten Coastal Bay.

Corresponding author:

Jl. Pasir Putih I Ancol Timur, Jakarta Utara 14430. Email: zuleha.ze@gmail.com 


\section{PENDAHULUAN}

Pesatnya pertumbuhan ekonomi di kawasan pesisir yang ditandai oleh ledakan pertumbuhan penduduk menjadikan kebutuhan akan ruang yang lebih luas. Hal ini menjadi permasalahan utama kotakota besar di seluruh dunia. Dalam kerangka penataan ruang perkotaan dan pemenuhan kebutuhan akan ruang baru di kawasan pesisir, sangat sulit menambah lahan ke arah darat, sehingga reklamasi kawasan pesisir menjadi pilihan utama yang harus ditempuh. Kebutuhan bahan timbunan untuk aktivitas reklamasi pada skala kecil dapat dipenuhi di darat, tetapi untuk skala besar diperlukan volume bahan timbunan yang sangat besar, sehingga pasir laut sebagai bahan timbunan menjadi pilihan utama (Husrin \& Prihantono, 2014).

Pasir laut dalam Keputusan Presiden Nomor 33 Tahun 2002 tentang Pengendalian dan Pengawasan Pengusahaan Pasir Laut, adalah bahan galian pasir yang terletak di wilayah perairan Indonesia yang tidak mengandung unsur mineral golongan A dan/atau golongan $B$ dalam jumlah yang berarti ditinjau dari segi ekonomi pertambangan. Penambangan pasir laut adalah memindahkan secara fisik sedimen atau material lain dari dasar laut ke suatu lokasi, yang diawali dengan kegiatan pengerukan, kemudian dilanjutkan dengan pengangkutan dan pengumpulan sedimen atau materi lain tersebut di tempat lain (Mukhtasor, 2007). Penambangan pasir laut dapat meningkatkan kekeruhan perairan, akibat pengadukan sedimen dasar laut. Peningkatan kekeruhan berpengaruh pada pada biota laut lainnya karena menyebabkan kematian telur dan larva karena hilangnya sedimen habitat mereka, serta ikan dan udang mengalami kesulitan untuk bernafas (Mukhtasor, 2007).

Kabupaten Serang disinyalir memiliki potensi pasir laut yang melimpah. Sedimen dasar laut berasal dari sungai-sungai di Kabupaten Serang dan Kabupaten Tangerang yang bermuara di Teluk Banten. Penambangan pasir laut yang terdekat dengan perairan Teluk Banten dilakukan oleh Pihak Swasta yang mulai melakukan penambangan sejak tahun 2004 hingga tahun 2015. Perairan Teluk Banten telah tercemar yang diindikasikan meningkatnya padatan tersuspensi atau Total Suspended Solid (TSS) hingga melampaui ambang batas baku mutu lingkungan (data terlampir).

Rumusan masalah dalam penelitian ini adalah belum adanya kajian ilmiah lingkungan mengenai pengaruh penambangan pasir laut di Teluk Banten. Untuk itu penellitian ini dilakukan dengan tujuan untuk mengidentifikasi aktivitas penambangan pasir laut di Teluk Banten, dan menganalisis seberapa besar pengaruh penambangan pasir laut pada kekeruhan perairan Teluk Banten. Hipotesis penelitian ini adalah aktivitas penambangan pasir laut meningkatkan kekeruahan perairan Teluk Banten.

\section{METODE PENELITIAN}

\section{Tempat dan Waktu Penelitian}

Penelitian dilaksanakan di Perairan Teluk Banten, Kabupaten Serang. Pengumpulan data dilakukan selama 4 (empat) bulan, pada Desember 2014 - Maret 2015.

\section{Pengumpulan Data}

Data yang dikumpulkan berupa data sekunder yaitu data aktivitas penambangan pasir laut dan data kekeruhan perairan. Data aktivitas penambangan pasir laut diperoleh dari Dinas Kelautan, Perikanan, Energi, dan Sumber Daya Mineral (DKPESDM) Kabupaten Serang berupa data lokasi pengerukan pasir laut, volume pengerukan pasir laut, dan peruntukan hasil pengerukan pasir laut yang dilakukan oleh PT. X di Teluk Banten. Data kekeruhan berupa data Total Suspended Solid (TSS) diperoleh dari Badan Lingkungan Hidup Daerah (BLHD) Kabupaten Serang yaitu data TSS yang diukur oleh PT. $X$ di lokasi penambangan pasir laut.

\section{Analisis Data}

Keterkaitan penambangan pasir laut dengan kekeruhan perairan didapat dengan menghubungkan data volume produksi pasir laut dengan data TSS. Analisis dilakukan dengan metode korelasi dan regresi polinomial orde 2. Pemilihan regresi polinomial dilakukan untuk menentukan fungsi polinomial yang paling sesuai dengan sekumpulan titik data $(\mathrm{Xn}, \mathrm{Yn})$ yang diketahui. Regresi polinomial menghasilkan pendekatan yang lebih akurat dibandingkan regresi linier. Pola pendekatan kurva lengkung menghasilkan nilai kesalahan perkiraan (error) lebih kecil ketimbang menggunakan pola garis lurus linier. Hal ini ditunjukkan dengan nilai koefisien korelasi yang mendekati 1. adalah:

Persamaan kurva regresi polinomial orde 2

$$
y(x)=a 0+a 1 x+a 2 x^{2}
$$

di mana, a0, a1, dan a2 dapat dihitung dari persamaan linier sebagai berikut:

$$
a_{0} N+a_{1} \sum_{i=1}^{N} x_{i}+a_{2} \sum_{i=1}^{N} x_{i}^{2}=\sum_{i=1}^{N} y_{i}
$$




$$
\begin{aligned}
& a_{0} \sum_{i=1}^{N} x_{i}+a_{1} \sum_{i=1}^{N} x_{i}^{2}+a_{2} \sum_{i=1}^{N} x_{i}^{3}=\sum_{i=1}^{N} x_{i} y_{i} \\
& a_{0} \sum_{i=1}^{N} x_{i}^{2}+a_{1} \sum_{i=1}^{N} x_{i}^{3}+a_{2} \sum_{i=1}^{N} x_{i}^{4}=\sum_{i=1}^{N} x_{i}^{2} y_{i}
\end{aligned}
$$

atau dalam bentuk matriks:

$$
\left[\begin{array}{ccc}
\sum_{i=1}^{N} 1 & \sum_{i=1}^{N} x_{i} & \sum_{i=1}^{N} x_{i}^{2} \\
\sum_{i=1}^{N} x_{i} & \sum_{i=1}^{N} x_{i}^{2} & \sum_{i=1}^{N} x_{i}^{3} \\
\sum_{i=1}^{N} x_{i}^{2} & \sum_{i=1}^{N} x_{i}^{3} & \sum_{i=1}^{N} x_{i}^{4}
\end{array}\right]\left\{\begin{array}{l}
\sum_{i=1}^{N} y_{i} \\
a_{1} \\
a_{2}
\end{array}\right\}=\left\{\begin{array}{c}
a_{i=1}^{N} x_{i} y_{i} \\
\sum_{i=1}^{N} x_{i}^{2} y_{i}
\end{array}\right\}
$$

Nilai koefisien a0, a1, dan a2 dapat dihitung dengan menggunakan eliminasi Gauss/ Gauss-Jordan.

Koefisien korelasi $r$ dihitung dengan persamaan:

$r=\sqrt{ }\left(\left(D_{t}^{2}-D^{2}\right) /\left(D_{t}^{2}\right)\right)$

di mana,

$$
\begin{aligned}
& D^{2}=\sum_{i=1}^{N}\left\{y_{i}-y\left(x_{i}\right)\right\}^{2} \\
& D_{t}^{2}=\sum_{i=1}^{N}\left\{y_{i}-\bar{y}\right\}^{2} \quad \bar{y}=\frac{\sum y}{N}
\end{aligned}
$$

Untuk melakukan interpretasi mengenai kekuatan hubungan antar variabel diberikan kriteria sebagai berikut (Sarwono, 2012):

$0 \quad$ : Tidak ada korelasi antara dua variabel $0<r<0,25$ : Korelasi sangat lemah

\author{
$0,25<r<0,5$ : Korelasi cukup \\ $0,5<r<0,75$ : Korelasi kuat \\ $0,75<r<1 \quad$ : Korelasi sangat kuat \\ 1 : Korelasi sempurna \\ $r \quad=$ Koefisien korelasi
}

\section{HASIL DAN PEMBAHASAN}

\section{Aktivitas Penambangan Pasir Laut}

Perusahaan yang memiliki izin usaha pertambangan operasi produksi pasir laut yang terdekat dengan Teluk Banten adalah PT. X. Izin kuasa pertambangan eksplorasi PT. $X$ berdasarkan Keputusan Direktur Jenderal Pertambangan Umum No. 152.K/2013/DDJP/1996 tanggal 3 Mei 1996 tentang Pemberi Kuasa Pertambangan Eksplorasi. Penilaian kelayakan kegiatan untuk lingkungan telah dilakukan berdasarkan Analisis Mengenai Dampak Lingkungan (AMDAL). Pada 2003 perusahaan PT. X memperoleh izin pertambangan pasir laut berdasarkan Surat Keputusan Bupati Kabupaten Serang No.540/Kep.68/ Huk/2003 tentang Pemberian Izin Pertambangan Pasir Laut Lepas Pantai di Desa Lontar Kecamatan Tirtayasa. Izin tersebut diperpanjang pada 2005 dan 2006 (Kusumawati, 2008), 2011 (Mongabay, 2013), dan 2014 (DKPESDM, 2015). Area penambangan pasir laut PT. X di Teluk Banten seluas 3.674 Ha terbagi menjadi 4 area (Tabel 1), berdasarkan Peraturan Daerah Kabupaten Serang Nomor 7 tahun 2011 tentang Pengelolaan Pertambangan yang mensyaratkan luas areal pertambangan pasir laut paling banyak $1.000 \mathrm{Ha}$.

Lokasi penambangan pasir laut yang dilakukan oleh PT. X terletak di kawasan perairan Desa Pulo Panjang Kecamatan Pulo Ampel dan Desa Lontar Kecamatan Tirtayasa (Gambar 1). Penambangan

Table 1. Lokasi Penambangan Pasir Laut PT. X di Teluk Banten

\begin{tabular}{lll}
\hline Area & Lokasi & Luas Area (Ha) \\
\hline Blok 1 & $\begin{array}{l}\text { Lepas pantai utara Desa Pulo } \\
\text { Panjang Kecamatan Pulo Ampel } \\
\text { Kabupaten Serang }\end{array}$ & 1.000 \\
\hline Blok 2 & $\begin{array}{l}\text { Lepas pantai utara Desa Pulo Panjang } \\
\text { Kecamatan Pulo Ampel } \\
\text { Kabupaten Serang }\end{array}$ & 905 \\
Blok 3 & $\begin{array}{l}\text { Lepas pantai utara Desa Lontar } \\
\text { Kecamatan Tirtayasa } \\
\text { Kabupaten Serang }\end{array}$ & 769 \\
\hline Blok 4 & $\begin{array}{l}\text { Lepas pantai utara Desa Lontar } \\
\text { Kecamatan Tirtayasa } \\
\text { Kabupaten Serang }\end{array}$ & \\
\hline
\end{tabular}

Sumber: Keputusan Bupati Serang Nomor 540/010/IUP/BPTPM/2014, Nomor 540/011/IUP/ BPTPM/2014, Nomor 540/012/IUP/BPTPM/2014, dan Nomor 540/008/IUP/BPTPM/2014. 
pasir laut oleh PT. X dilakukan pada 2004, 2012, 2013, 2014, dan 2015. Produksi pasir laut tidak dilakukan pada 2005-2011. Produksi pasir laut terbanyak pada 2013 yaitu sebesar 4.807.558 $\mathrm{m}^{3}$. Produksi pasir laut pada 2004, 2012, 2014 dan Januari 2015 yaitu 2.194.103 $\mathrm{m}^{3}, 3.884 .783 \mathrm{~m}^{3}, 103.993 \mathrm{~m}^{3}$, dan. 523.535 $\mathrm{m}^{3}$. Total produksi pasir laut dari tahun 2004 hingga Januari 2015 adalah $11.513 .972 \mathrm{~m}^{3}$. Perpanjangan izin usaha pertambangan pasir laut PT. $X$ memang selalu dikeluarkan oleh Bupati Serang, namun bukan berarti selalu dilakukan penambangan pasir laut di area penambangan pasir laut oleh PT. X. Penambangan pasir laut oleh PT. X dilaksanakan mulai tahun 2004 dan setelah itu tidak ada penambangan pasir laut hingga tahun 2011. Penambangan pasir laut kembali dilakukan pada 2012 hingga tahun 2015. Hal ini didasarkan pada kontrak kerjasama PT. $\mathrm{X}$ dengan konsumen pasir laut. Produksi Pasir Laut yang dilakukan oleh PT. X di Teluk Banten diperlihatkan pada Gambar 2. Berdasarkan laporan produksi pertambangan yang disampaikan PT. $X$ kepada DKPESDM Kabupaten Serang, pasir laut yang diproduksi oleh PT. X dari perairan Teluk Banten diperuntukkan bagi reklamasi Pantai Indah Kapuk di Teluk Jakarta.

Kegiatan penambangan pasir laut oleh PT. $X$ merupakan salah satu penyumbang pendapatan daerah Kabupaten Serang melalui pajak daerah. Perda Kabupaten Serang Nomor 5 Tahun 2010 tentang Pajak Daerah, mengatur kegiatan-kegiatan yang dikenai pajak daerah diantaranya adalah mineral bukan logam dan batuan. Setiap kegiatan pengambilan mineral bukan logam dan batuan termasuk di dalamnya pasir dikenakan pajak sebesar $15 \%$ dari nilai jual hasil pengambilan mineral bukan logam dan batuan tersebut. Dengan demikian, aktivitas penambangan pasir laut PT. X telah memberikan pendapatan daerah melalui pajak mineral bukan logam dan batuan. Penambangan pasir laut menyumbang pendapatan asli daerah (PAD) Kabupaten Serang sebesar 30 milyar rupiah pada 2013 (Husrin \& Prihantono, 2014).

\section{Pengaruh Penambangan Pasir Laut pada Kekeruhan Perairan Teuk Banten}

Penambangan pasir laut oleh PT. $X$ telah meningkatkan kekeruhan di perairan Teluk Banten, berdasarkan data produksi pasir laut PT. $X$ dan data kekeruhan (TSS ) di Perairan Teluk Banten seperti yang terlihat dalam Tabel 2.

Hubungan antara produksi pasir laut dengan TSS perairan Teluk Banten ditentukan dengan korelasi dan regresi. Regresi yang sesuai untuk menghubungkan antara data produksi pasir laut dengan data TSS adalah regresi polinomial orde 2 (perhitungan terlampir), dan diperoleh persamaan regresinya adalah:

$\left.y(x)=90,8494+9,2392 \cdot 10^{-3} x-1,3059 \cdot 10^{-7} x^{2} \ldots .5\right)$

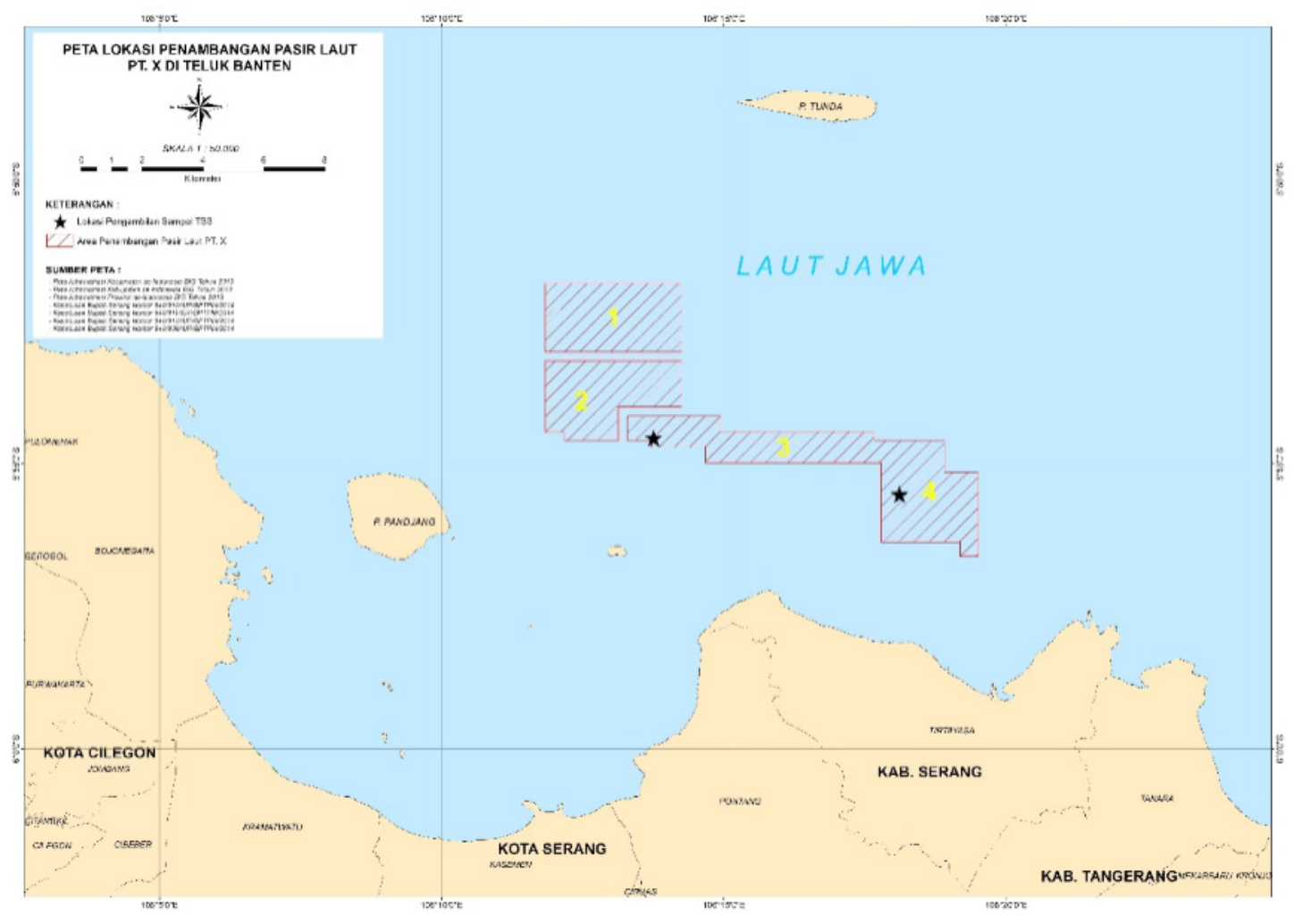

Gambar 1. Lokasi Penambangan Pasir Laut PT. X di Teluk Banten. 
Table 2.

Produksi Pasir Laut PT. X dan TSS Perairan Teluk Banten

\begin{tabular}{lll}
\hline Tanggal & $\begin{array}{l}\text { Produksi } \\
\text { Pasir Laut }\left(\mathbf{m}^{3}\right)\end{array}$ & TSS (mg/L) \\
\hline 13 Juli 2013 & 15.974 & 214 \\
22 Agustus 2013 & 24.697 & 236 \\
25 September 2013 & 0 & 102 \\
5 November 2013 & 3.508 & 105 \\
\hline
\end{tabular}

sumber: PT. X, 2013

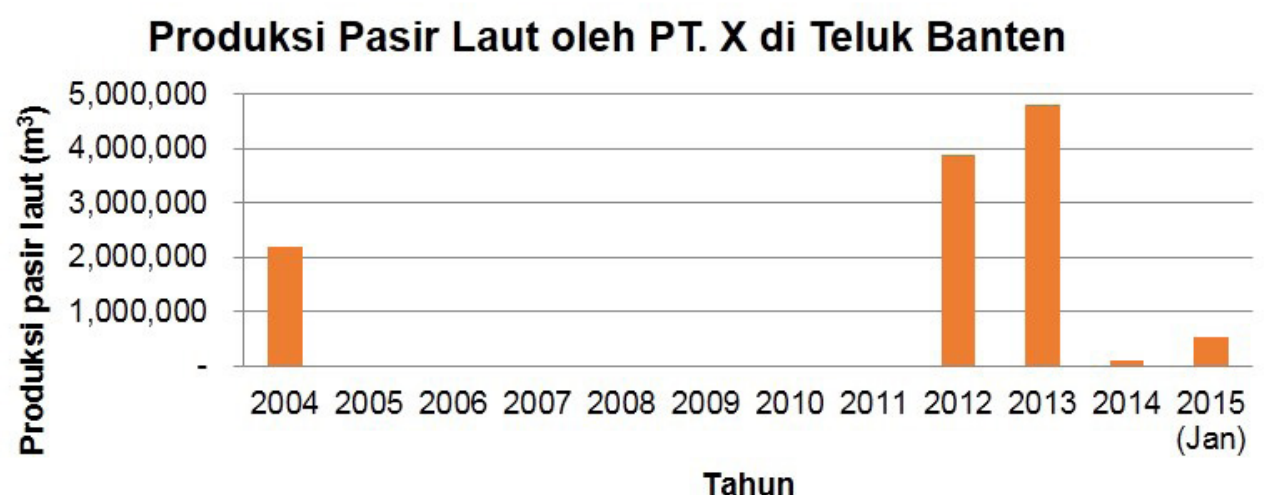

Gambar 2. Produksi Pasir Laut oleh PT. X di Teluk Banten.

(Sumber: DKPESDM Kabupaten Serang, 2015)

dengan:

$y(x)=$ TSS $(\mathrm{mg} / \mathrm{L})$

$\mathrm{x} \quad=$ Produksi pasir laut $\left(\mathrm{m}^{3}\right)$

Perhitungan korelasi (terlampir) mendapatkan nilai koefisien korelasi ( $r$ ) sebesar 0,9835. Kekuatan hubungan antar variabel produksi pasir laut dengan TSS ditunjukkan dengan nilai koefisien korelasi sebesar 0,9835 yang terletak pada kisaran $0,75<r<1$. Hal ini memperlihatkan hubungan yang sangat kuat antara produksi pasir laut dengan TSS. Hubungan antara produksi pasir laut dengan TSS ditunjukkan dengan persamaan regresi $\mathrm{y}(\mathrm{x})=90,8494+$ $9,2392 \cdot 10^{-3} \cdot x-1,3059 \cdot 10^{-7} \cdot x^{2}$ dengan nilai koefisien determinasi (R2) sebesar 0,9672. Berdasarkan nilai koefisien determinasi sebesar 0,9672 memperlihatkan bahwa dengan menggunakan persamaan regresi (persamaan 4.1), 96,72\% TSS ditentukan oleh aktivitas penambangan pasir laut, sedangkan 3,28\% ditentukan oleh faktor lain. Persamaan regresi memperlihatkan bahwa jika tidak ada penambangan pasir laut oleh PT. $X(x=0)$, maka nilai TSS di perairan Teluk Banten adalah 90,8494 mg/l, yang berarti perairan Teluk Banten keruh . Hal ini memperlihatkan selain aktivitas penambangan pasir laut, terdapat aktivitas lain yang menyebabkan peningkatan kekeruhan di Teluk Banten. Kekeruhan di pantai utara Kabupaten Serang juga berasal dari kedua muara sungai yang besar yaitu Sungai Ciujung dan Sungai Cidurian. Pada muara sungai, kekeruhan terutama berasal dari masukan air sungai yang keruh karena mengandung banyak muatan sedimen yang disebabkan oleh penebangan hutan dan kegiatan pertanian di daerah hulu yang tidak berwawasan lingkungan serta limbah domestik dan industri. Nilai $x=0$ hanyalah merepresentasikan sebagai tidak adanya kegiatan penambangan pasir pada tahun pengamatan. Tingginya nilai TSS walaupun tidak ada kegiatan penambangan pasir tersebut diduga juga dapat terjadi akibat penambangan pasir tahun sebelum-sebelumnya, karena material tersuspensi akibat penambangan pasir laut membutuhkan waktu yang lama untuk mengendap (Mukhtasor, 2007). Jika tidak ada penambangan pasir laut perairan sudah keruh, apalagi bila ada penambangan pasir, pastinya akan menambah lagi kekeruhan yang ada.

Hubungan antara penambangan pasir laut dengan kekeruhan diperlihatkan oleh Gambar 3. Gambar 3 memperlihatkan bahwa dengan semakin meningkatnya produksi penambangan pasir laut oleh PT. $X$ akan semakin meningkatkan TSS di perairan Teluk Banten.

Material dasar laut tidak semuanya adalah fraksi pasir, beberapa tercampur fraksi debu atau lumpur, maka aktivitas penambangan pasir laut yang tidak dilakukan secara hati-hati justru akan merusak ekosistem sumber daya laut. Tercampurnya fraksi 


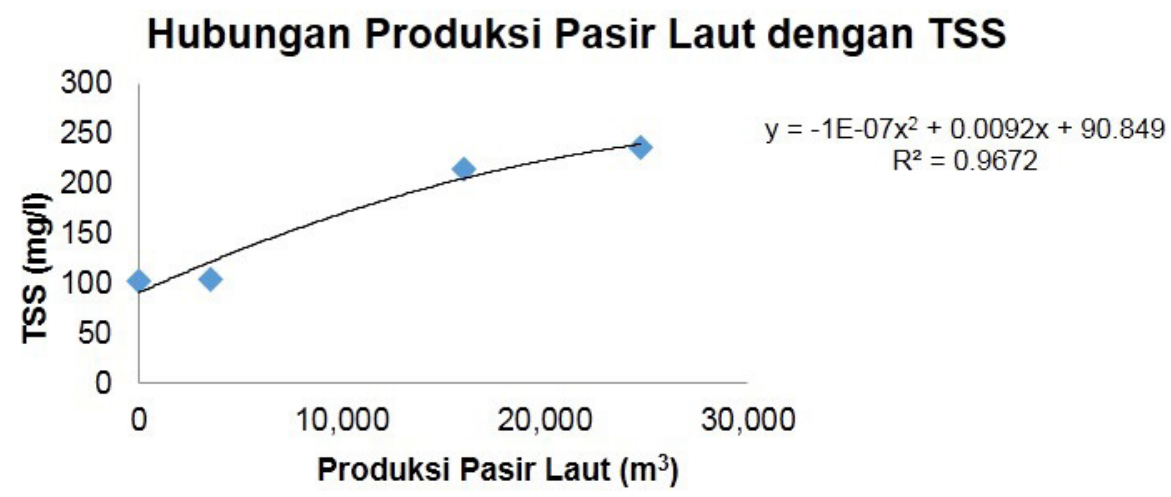

Gambar 3. Hubungan Penambangan Pasir Laut PT. X dengan Kekeruhan Teluk Banten.

lumpur yang berasal dari sedimen tersuspensi, menyebabnya keruhnya perairan di sekitar area penambangan pasir laut. Selain aktivitas pengerukan atau penambangan pasir, aktivitas kapal baik kapal untuk eksplorasi, eksploitasi, maupun kapal pengangkutan juga mempengaruhi ekosistem laut melalui distribusi atau sebaran sedimen hasil kerukan, sehingga perairan menjadi keruh. Semakin lama aktivitas penambangan dan semakin banyak lalu lintas kapal di kawasan penambangan menyebabkan semakin luas sebaran dan semakin lama sedimen mengendap, sehingga perairan tetap keruh.

Lokasi penambangan pasir laut PT. $X$ terletak di ekosistem perairan Teluk Banten. Aktivitas penambangan pasir laut memberikan dampak negatif pada ekosistem laut, berupa pencemaran air laut (kekeruhan) di Teluk Banten. Kekeruhan memang dampak dari aktivitas penambangan pasir laut, akan tetapi hal ini tidak boleh menjadi pembenaran (alasan) untuk mentolerir kelalaian mengendalikan dampak tersebut. Penambangan pasir laut oleh PT. $X$ telah menyebabkan peningkatan TSS di perairan Teluk Banten hingga melampaui Baku Mutu Lingkungan. Baku Mutu Lingkungan untuk biota adalah $<80 \mathrm{mg} / \mathrm{l}$ (Keputusan Menteri Lingkungan Hidup No 51 Tahun 2004 tentang Baku mutu Air Laut).

Kekeruhan perairan Teluk Banten yang telah melampaui baku mutu dapat berpengaruh pada proses fotosintesis fitoplankton di perairan Teluk Banten, sehingga dapat menghambat pertumbuhannya dan juga berpengaruh pada biotalainnya karena fitoplankton adalah produktivitas primer suatu siklus kehidupan di lingkungan laut. Kekeruhan juga berpengaruh pada biota di Perairan Teluk Banten lainnya karena menyebabkan kesulitan untuk bernafas. Kondisi tersebut menyebabkan ikan mati atau bermigrasi ke tempat lain. Berkurangnya ikan berpengaruh pada hasil tangkapan nelayan.

Aktivitas pembangunan tidak mungkin ditiadakan atau dihilangkan secara total, namun perlu upaya untuk meminimalkan dampak negatifnya sehingga kerusakan dan pencemaran yang timbul dapat ditoleransi oleh lingkungan. Peningkatan kekeruhan di perairan Teluk Banten memperlihatkan bahwa ada dampak negatif dari penambangan pasir. Perizinan, menjadi salah satu upaya dalam pengelolaan penambangan pasir. Perlu dikaji pemberian izin, agar izin tidak dikeluarkan kecuali kondisi perairan telah pulih kembali (self purification). Pemberian izin juga perlu memperhatikan zona penangkapan yang bersebelahan dengan zona penambangan, dan banyak aktivitas penangkapan ikan di sekitar lokasi penambangan.

\section{KESIMPULAN}

Kegiatan penambangan pasir di Teluk Banten oleh PT. X dilakukan di perairan Desa Lontar dan Pulo Panjang berdasarkan kontrak pekerjaan yang telah dilakukan pada 2004, 2012, 2013, 2014, dan 2015. Total produksi pasir laut dari tahun 2004 hingga 2015 sebesar $11.513 .972 \mathrm{~m}^{3}$. Pasir laut dari perairan Teluk Banten yang diambil oleh PT. X digunakan untuk reklamasi Pantai Indah Kapuk.

Penambangan pasir laut meningkatkan padatan tersuspensi di perairan Teluk Banten, dengan persamaan regresi polinomial orde 2 yaitu $y(x)=$ $90,8494+9,2392 \cdot 10^{-3} x-1,3059 \cdot 10^{-7} x^{2}$ dengan nilai korelasi $r=0,9835$.

Aktivitas penambangan pasir laut dapat dipertimbangkan untuk dihentikan sementara karena telah meningkatkan TSS perairan Teluk Banten hingga melampaui ambang batas baku mutu lingkungan.

\section{PERSANTUNAN}

Artikel ini adalah bagian dari penelitian tesis yang berjudul Pengaruh Penambangan Pasir Laut pada Produktivitas Perairan (kasus: Teluk Banten Kabupaten Serang) dengan penulis Zuleha Ernas, tahun 2016. 
Penulis mengucapkan terima kasih kepada Badan Lingkungan Hidup Daerah Kabupaten Serang yang telah menyediakan data kualitas air Teluk Banten dan laporan UKL/UPL PT. X. Penulis juga mengucapkan terimakasih kepada Dinas Kelautan, Perikanan, Energi, dan Sumber Daya Mineral Kabupaten Serang yang telah membantu menyediakan data produksi pasir laut $\mathrm{PT}$. X dan izin usaha pertambangan $\mathrm{PT}$. $\mathrm{X}$.

\section{DAFTAR PUSTAKA}

Badan Lingkungan Hidup Daerah (BLHD) Kabupaten Serang. (2014). Data kualitas air Teluk Banten periode 2009-2013. Serang.

Dinas Kelautan, Perikanan, Energi, dan Sumber Daya Mineral (DKPESDM) Kabupaten Serang. (2015). Produksi Pasir Laut. Banten: DKPESDM Kabupaten Serang.

Husrin, S. \& Prihantono, J. (2014). Penambangan pasir laut. Bogor: IPB Press.

Kabupaten Serang. (2011). Rencana Strategis Wilayah Pesisir dan Pulau-pulau Kecil Kabupaten Serang. Serang.

Keputusan Bupati Serang Nomor 540/008/IUP/ BPTPM/2014 tanggal 17 April 2014 tentang Izin Usaha Pertambangan Operasi Produksi Pasir Laut di Lepas Pantai Utara Kabupaten Serang A/N PT. X (Blok 4).

Keputusan Bupati Serang Nomor 540/010/IUP/ BPTPM/2014 tanggal 17 April 2014 tentang Izin Usaha Pertambangan Operasi Produksi Pasir Laut di Lepas Pantai Utara Kabupaten Serang A/N PT. X (Blok 1).

Keputusan Bupati Serang Nomor 540/011/IUP/ BPTPM/2014 tanggal 17 April 2014 tentang Izin Usaha Pertambangan Operasi Produksi Pasir Laut di Lepas Pantai Utara Kabupaten Serang A/N PT. X (Blok 2).

Keputusan Bupati Serang Nomor 540/012/IUP/ BPTPM/2014 tanggal 17 April 2014 tentang Izin Usaha Pertambangan Operasi Produksi Pasir Laut di Lepas Pantai Utara Kabupaten Serang A/N PT. X (Blok 3).

Keputusan Bupati Serang Nomor 540/Kep.68/Huk/2003 tentang Pemberian Izin Pertambangan Pasir Laut Lepas Pantai di Desa Lontar Kecamatan Tirtayasa.

Keputusan Direktur Jenderal Pertambangan Umum No. 152.K/2013/DDJP/1996 tanggal 3 Mei
1996 tentang Pemberi Kuasa Pertambangan Eksplorasi.

Kusumawati, L. (2008). Penambangan pasir laut di Kabupaten Serang studi kasus di perairan Desa Lontar Kecamatan Tirtayasa (Tesis). Yogyakarta: Universitas Gadjah Mada.

Luknanto. D. (1992). Regresi kuadrat terkecil untuk kalibrasi bangunan ukur debit.

Manik, K.E.S. (2009). Pengelolaan lingkungan hidup. Jakarta: Djambatan.

Mongabay.co.id. (2013, November 13). http://www. mongabay.co.id/2013/11/13/ kementeriankelautan-dan-perikanan-janji-selidiki-tambangpasir-di-teluk-lontar.

Mukhtasor. (2007). Pencemaran pesisir dan laut. Jakarta: PT. Pradnya Paramita.

Peraturan Daerah Kabupaten Serang Nomor 5 tahun 2010 tentang Pajak Daerah.

Peraturan Daerah Kabupaten Serang Nomor 7 tahun 2011 tentang Pengelolaan Pertambangan.

PT. X. (2002). Analisis Dampak Lingkungan (ANDAL) Rencana Pertambangan Endapan Pasir Urug Lepas Pantai Pada KW. F00313 Kabupaten Serang Provinsi Banten. Jakarta.

PT. X. (2013). Laporan produksi pertambangan Agustus 2013. Jakarta.

PT. X. (2013). Laporan produksi pertambangan Februari 2013. Jakarta.

PT. X. (2013). Laporan produksi pertambangan Januari 2013. Jakarta.

PT. X. (2013). Laporan produksi pertambangan Juli 2013. Jakarta.

PT. X. (2013). Laporan produksi pertambangan Juni 2013. Jakarta.

PT. X. (2013). Laporan produksi pertambangan Maret 2013. Jakarta.

PT. X. (2013). Laporan produksi pertambangan Mei 2013. Jakarta.

PT. X. (2013). Laporan produksi pertambangan November 2013. Jakarta.

PT. X. (2013). Laporan produksi pertambangan 
September 2013. Jakarta.

PT. X. (2013). Laporan Upaya Pengelolaan Lingkungan dan Upaya Pemantauan Lingkungan (UKL/UPL) Penambangan Pasir Laut Lepas Pantai Periode: Juli-September 2013 Desa Lontar Kecamatan Tirtayasa, Tanjung Pontang Kecamatan Pontangl Kabupaten Serang. Jakarta.

PT. X. (2013). Laporan Upaya Pengelolaan Lingkungan dan Upaya Pemantauan Lingkungan (UKL/UPL) Penambangan Pasir Laut Lepas Pantai Periode: Oktober-Desember 2013 Desa Lontar Kecamatan Tirtayasa, Tanjung Pontang Kecamatan Pontang Kabupaten Serang. Jakarta.

PT. X. (2014). Laporan Upaya Pengelolaan Lingkungan dan Upaya Pemantauan Lingkungan (UKL/UPL) Penambangan Pasir Laut Lepas Pantai Periode: Oktober-Desember 2014 Desa Lontar Kecamatan Tirtayasa, Tanjung Pontang Kecamatan Pontang, P. Panjang Kec. P. Ampel Kabupaten Serang. Jakarta.

PT. X. (2015). Laporan produksi pertambangan Desember 2014. Jakarta.

Lampiran Tabel Kedalaman Perairan pada lokasi sampling

\begin{tabular}{llll}
\hline Tahun & Lokasi & Bulan & TSS (mg/l) \\
\hline 1998 & Sekitar Pulo Panjang & Agustus & $2-4$ \\
2009 & Pulo Ampel - Bojonegara & Feb & $45-76$ \\
& & April & $21-67$ \\
& & Juni & $19,3-27,1$ \\
\multirow{2}{*}{2010} & \multirow{2}{*}{ Pulo Ampel - Bojonegara } & Agustus & $17,2-31,2$ \\
& & Feb & $146-182$ \\
& & April & $292-384$ \\
2011 & \multirow{3}{*}{ Pulo Ampel - Bojonegara } & Juni & $136-436$ \\
& & Feb & $102-359$ \\
& & April & $168-302$ \\
& & Juni & $211-403$ \\
& & Agustus & $200-304$ \\
2013 & Pulo Ampel - Bojonegara & Oktober & $204-257$ \\
& & Desember236-332 & $142-179$ \\
& & Oktober & $152-187$ \\
\hline
\end{tabular}

